\title{
Antitrust, Competition Policy, and Inequality
}

Jonathan B. Baker

American University Washington College of Law, jbaker@wcl.american.edu

Steven C. Salop

Georgetown University Law Center, salop@law.georgetown.edu

This paper can be downloaded free of charge from:

https://scholarship.law.georgetown.edu/facpub/1462

http://ssrn.com/abstract=2567767

104 Geo. L.J. 1-28 (2015)

This open-access article is brought to you by the Georgetown Law Library. Posted with permission of the author. Follow this and additional works at: https://scholarship.law.georgetown.edu/facpub

Part of the Antitrust and Trade Regulation Commons, Ethics and Political Philosophy Commons, Income Distribution Commons, Political Economy Commons, Public Economics Commons, and the Public Policy Commons 


\title{
Antitrust, Competition Policy, and Inequality
}

\author{
JONATHAN B. BAKER AND STEVEN C. SALOP*
}

\section{INTRODUCTION}

Economic inequality recently has entered the political discourse in a highly visible way. Inequality and "middle-class economics" were the centerpieces of President Obama's 2015 State of the Union address. ${ }^{1}$ Leading potential Republican presidential nominees have also spoken out on the problem of inequality in the United States. ${ }^{2}$

This political impact is not a surprise. As the U.S. economy has begun to recover from the Great Recession since mid-2009, the rising tide has not lifted all boats. To the contrary, median income and wealth both declined in real terms between 2010 and 2013. ${ }^{3}$ Over essentially the same period, the real income of the top $1 \%$ grew by $31.4 \%,{ }^{4}$ and the income

* Professor of Law, American University Washington College of Law, and Professor of Economics and Law, Georgetown University Law Center, respectively. The authors are grateful to Andrew Gavil, William Kovacic, and John Woodbury for helpful comments and discussions.

1. President Barack Obama, Remarks by the President in State of the Union Address (Jan. 25, 2015), available at https://www.whitehouse.gov/the-press-office/2015/01/20/ remarks-president-state-union-address-january-20-2015.

2. See Catherine Rampell, Republicans Have Started to Care About Income Inequality, WASH. POST (Jan. 22, 2015), http://www.washingtonpost.com/opinions/catherine-rampell -republicans-have-started-to-care-about-income-inequality/2015/01/22/f1ee7686-a27611e4-903f-9f2faf7cd9fe_story.html.

3. Edward N. Wolff, Household Wealth Trends in the United States, 1962-2013: What Happened Over the Great Recession? 49 tbl.1 (Nat'l Bureau of Econ. Research, Working Paper No. 20733, Dec. 2014).

4. Updated Tables and Figures (2013) to Thomas Piketty \& Emmanuel Saez, Income Inequality in the United States, 1913-1998, 118 Q. J. ECON. 1 (2003), http://elsa.berkeley. edu/ saez/Tab Fig2012prel.xls (last visited Mar. 18, 2015). During the 2009 to 2013 economic recovery, the top $1 \%$ of the income distribution captured $95 \%$ of the economy's overall income growth. Id. A recent study purporting to challenge this claim nonetheless acknowledges that "the lion's share of growth" still went to the top $1 \%$ of the income distribution, even after accounting for changes to the tax law that provided incentives for the wealthy to take capital gains in 2012 rather than 2013. STEPHEN ROSE, THE INFORMATion TECHNOLOgy \& InNOvation Foundation, The FAlse Claim That InEQuAliTY ROSE DURING THE GREAT RECESSION 4 (2015), available at http://www2.itif.org /2015-inequality-rose.pdf. That study also contends that income inequality decreased between 2007 and 2009, primarily because the incomes of the wealthiest experienced substantial capital losses from securities market fluctuations while public policies involv- 
share of the top $1 \%$ increased from $17.2 \%$ to $19.8 \% .{ }^{5}$ The fact that economic growth has effectively been appropriated by those already well off, leaving the median household less well off, raises serious economic, political, and moral issues.

The divergence in economic fortunes between those at the very top and the rest of society is not a temporary phenomenon. Median income has been declining since 2000, well before the start of the Great Recession, while real GDP is more than $25 \%$ higher now. ${ }^{6}$ The economic position of the richest Americans has improved during the past decade, while most households have struggled or lost ground. ${ }^{7}$ In fact, inequality in the U.S. has been growing since the 1980s. Between 1982 and 2013, the share of income going to the top $1 \%$ increased from $12.8 \%$ to $19.8 \%$, and the share going to the bottom $40 \%$ fell from $12.3 \%$ to $9.4 \%{ }^{8}$ The average income of the top $1 \%$ rose by $90 \%$ between 1983 and 2013, while the average income of the bottom $60 \%$ declined by more than $4 \%$ over the same period. ${ }^{9}$

ing taxes and transfers partially cushioned the income declines of other cohorts. Id. at 56 . The study's view that the incomes of the wealthiest are highly sensitive to capital market fluctuations is consistent with the data indicating that equity ownership is concentrated at the top of the wealth distribution, infra note 47, and the study does not call into question the broad trends in inequality we highlight.

5. Wolff, supra note 3, at 50 tbl.2 (statistics for 2009 and 2013).

6. United States Bureau of the Census, Real Median Household Income in the United States, FEDERAL RESERVE BANK OF ST. LOUIS, http://research.stlouisfed.org/fred2/series /MEHOINUSA672N (last visited Mar. 20, 2015); United States Bureau of Economic Analysis, Real Gross Domestic Product, 3 Decimal, Federal Reserve Bank of ST. LOUIS, http://research.stlouisfed.org/fred2/series/GDPC96 (last visited Mar. 20, 2015); see also Barry P. Bosworth, Sources of Real Wage Stagnation, BROOKINGS (Dec. 22, 2014, 11:02 AM), http://www.brookings.edu/research/opinions/2014/12/22-sources-realwage-stagnation-bosworth (documenting a slowdown in real wages and labor productivity in the U.S. since 2005, and demonstrating that non-wage supplements (benefits) have not grown relative to wages and salaries).

7. See Wolff, supra note 3, at 50 tbl.2 (the income share of the top $1 \%$ increased between 2009 and 2013, while the share of other groups stayed about the same or lost ground; wealth shares changed in a similar way between 2010 and 2013, except that the wealth share of the $95 \%$ to $99 \%$ group also rose).

8. Wolff, supra note 3, at 50 tbl.2. See also Facundo Alvaredo, Anthony B. Atkinson, Thomas Piketty \& Emmanuel Saez, The Top 1 Percent in International and Historical Perspective, 27 J. ECON. PERSP. 3, 4 (2013) (the income share of the top 1\% more than doubled from $9 \%$ in 1976 to $20 \%$ in 2001, while the rise in the income share of the group from the 95th to 99th percentile was only 3 percentage points).

9. Wolff, supra note 3, at 51 tbl.3. According to Wolff, the mean income of the bottom $40 \%$ fell by $4.3 \%$, and the mean income of the next $20 \%$ declined by $5.6 \%$. Cf. Piketty \& 
Wealth inequality exhibits a similar trend. By one measure, the wealth share of the bottom $90 \%$ has steadily declined since the mid-1980s, while the wealth share of the highest $0.1 \%$ has grown from $7 \%$ in 1979 to $22 \%$ in 2012. ${ }^{10}$ These data also show that the top $0.1 \%$ now account for virtually as much total wealth as the entire bottom $90 \% .{ }^{11}$ The 16,070 households in the top $0.01 \%$ collectively control $11 \%$ of all U.S. wealth, each with more than $\$ 111$ million in assets. ${ }^{12}$ Between 1983 and 2013, the average net worth of the top $1 \%$ rose by $81.6 \%$ while the average net worth of the bottom $60 \%$ declined, and, indeed, the average net worth of the bottom $40 \%$ is now negative. ${ }^{13}$

Inequality was an important political issue a century ago. ${ }^{14}$ It has become newsworthy again since the Occupy movement's protests against Wall Street on behalf of "the 99\%" in 2011, ${ }^{15}$ and the 2012 election campaign of Elizabeth Warren to the United States Senate. ${ }^{16}$ Best-selling

Saez, supra note 4 (reporting that from 1993 to 2012, the top 1\% incomes grew by 86.1\% while the bottom $99 \%$ incomes grew by $6.6 \%$ ).

10. Emmanuel Saez \& Gabriel Zucman, Wealth Inequality in the United States Since 1913: Evidence from Capitalized Income Tax Data 37 (Nat'l Bureau of Econ. Research, Working Paper No. 20625, Oct. 2014). But cf. Wojciech Kopczuk, What Do We Know About Evolution of Top Wealth Shares in the United States? 29 J. ECON. PERSP. 47 (2015) (while the share of wealth held by the top $10 \%$ has increased since the late 1980s, and one estimate of the share of wealth held by the top $1 \%$ and top $0.1 \%$ shows a steep increase during the same time period, other methods show a small increase in the share of wealth).

11. The bottom $90 \%$ have a $22.8 \%$ wealth share. Saez \& Zucman, supra note 10 , at 47 tbl.1.

12. Id.

13. Wolff, supra note 3 , at 51 tbl.3.

14. See Ellis W. Hawley, The New Deal and the Problem of Monopoly 281379 (1966) (describing New Deal attacks on concentrated wealth and economic power); SAMUEl P. HAYs, THE ResPonse to Industrialism, 1885-1914, at 37-43 (1957) (describing social and political conflict arising from the growing gulf between rich and poor during the Gilded Age and Progressive Era); $c f$. Maurice E. Stucke, Occupy Wall Street and Antitrust, 85 S. CAL. L. REV. POSTSCRIPT 32, 37-38 (2012) (observing that concerns with inequality were cited by drafters of the Sherman Act and by both the majority and the dissent in the famous antitrust decision in Standard Oil Co. v. United States, 221 U.S. 1 (1911)).

15. See generally Todd Gitlin, Where Are the Occupy Protesters Now?, THE GUARDIAN (June 17, 2014, 4:55 PM), http://www.theguardian.com/cities/2014/jun/17/whereoccupy-protesters-now-social-media; Roger Lowenstein, Occupy Wall Street: It's Not a Hippie Thing, BlOOMBERG Bus. WK. (Oct. 27, 2011), http://www.bloomberg.com/bw/ magazine/occupy-wall-street-its-not-a-hippie-thing-10272011.html.

16. See, e.g., Elizabeth Warren, What Happened to the Middle Class?, CNN (May 1, 2014, 10:16 AM), http://www.cnn.com/2014/05/01/opinion/warren-middle-class (advo- 
books by leading scholars have also sparked public discussion of inequality: Jacob S. Hacker and Paul Pierson's Winner-Take-All Politics: How Washington Made the Rich Richer-And Turned Its Back on the Middle Class in 2011, ${ }^{17}$ Joseph Stiglitz's The Price of Inequality in 2012, ${ }^{18}$ and Thomas Piketty's Capital in the Twenty-First Century in 2014. ${ }^{19}$

The careful data analysis of economists Emmanuel Saez, Thomas Piketty, and their co-authors has made a substantial contribution to understanding these concerns about inequality. Their data document that large income and wealth gaps have opened up between the top $0.1 \%$ and the rest of society. In Lawrence Summers's succinct summary, this research "has transformed political discourse and is a Nobel Prize-worthy contribution."20

Inequality of this magnitude raises serious economic, political and moral concerns. As recently summarized by Bill Gates, the wealthiest person in the world, "High levels of inequality are a problem-messing up economic incentives, tilting democracies in favor of powerful interests, and undercutting the ideal that all people are created equal. Capitalism does not self-correct toward greater equality-that is, excess wealth concentration can have a snowball effect if left unchecked.”21

Gates went on say that "[g]overnments can play a constructive role in offsetting the snowballing tendencies if and when they choose to do so."22 Inequality can be addressed through a panoply of public policies. This article examines how public concerns about growing inequality might spark proposals to modify antitrust and competition policy. It describes the channels through which market power contributes to inequality and sets forth a wide range of possible antitrust policy adjustments that might be considered in response to that market power or inequality more generally.

cating policies to address "the hollowing out of America's middle class").

17. Jacob S. Hacker \& PaUl Pierson, Winner-TaKe-All Politics: How Washington Made the Rich Richer-AND TuRned Its BACK ON THE MidDle Class (2012).

18. Joseph E. Stiglitz, The Price of Inequality: How Today’s Divided Society ENDANGERS OUR FUTURE (2012).

19. THOMAS PIKETTY, CAPITAL IN THE TWENTY-FIRST CENTURY (2014).

20. Lawrence H. Summers, The Inequality Puzzle, 2014 DemOCRACY J. 91, 92; cf. id. ("There can now be no doubt that the phenomenon of inequality is not dominantly about the inadequacy of the skills of lagging workers.").

21. Bill Gates, Why Inequality Matters, GATESNOTES (Oct. 13, 2014), http://www. gatesnotes.com/Books/Why-Inequality-Matters-Capital-in-21st-Century-Review.

22. Id. 
The aim of this article is to identify various potential policy options, while recognizing that some are more controversial and provocative than others. Our goal is to spur further discussion, not to offer definitive policy recommendations.

\section{THE ECONOMIC HARMS FROM INEQUALITY}

Some inequality is a natural byproduct of a market economy: the market generates winners and losers, and the prospect of economic success helps foster effort, investment, and innovation. But these positive effects on innovation and entrepreneurship do not automatically benefit everyone, as demonstrated by the fact that over the past quarter century labor productivity has increased steadily while hourly worker compensation has stagnated. ${ }^{23}$ More importantly, this observation does not automatically justify whatever inequality the market happens to produce. Inequality also involves social costs.

Interpersonal utility comparisons are beyond the scope of standard economic models. However, individuals generally and policy makers in particular do make such comparisons. We suspect that many people consider a wide economic gap between rich and poor to be objectionable. ${ }^{24}$ Using the language of economics, in terms of purchasing goods and services, one would say that a dollar of marginal income spent by a less wealthy person is generally more valuable socially than that marginal dollar of income spent by a very wealthy person. ${ }^{25}$ In populist lay terms, we

23. Josh Bivens, Elise Gould, LAwrence Mishel \& Heidi Shierholz, Econ. PoliCY INST., RAISING AMERICA's PAY 10 fig.A (2014), available at http://www.epi.org /publication/raising-americas-pay.

24. See generally John RAWLS, A TheORY OF JustiCE (1971); Colin F. Camerer \& Ernst Fehr, When Does “Economic Man” Dominate Social Behavior? 311 SCIENCE 47 (2006); Alan B. Krueger, Inequality, Too Much of a Good Thing, in INEQUALITY IN AMERICA: What Role FOR Human CAPITAl Policies? 1, 12-14 (James J. Heckman \& Alan B. Krueger eds., 2003) (surveying philosophical and religious objections to inequality); John A. List \& Todd L. Cherry, Examining the Role of Fairness in High Stakes Allocation Decisions, 65 J. ECON. BEHAV. \& ORG. 1 (2008); cf. BENJAMIN I. PAGE \& LAWRENCE R. JACOBS, Class WAR? What AMERICANS REALly THINK ABOUT ECONOMiC INEQUALITY 75-93 (2009) (documenting strong public concern about inequality and support for redistributive policies to enhance economic security).

25. The moral concern with economic inequality may go beyond income inequality, however. See Amartya K. Sen, From Income Inequality to Economic Inequality, $64 \mathrm{~S}$. ECon. J. 384 (1997); Carol Graham, The High Costs of Being Poor in America: Stress, 
expect most people would agree that it is more valuable to give an extra thousand dollars to a poor mother to spend on dental care and food for her children than to give it to an investment banker and his partners to spend on a fine dinner and wine.

In addition, inequality may undermine the legitimacy of our social order. ${ }^{26}$ The trend toward greater economic success at the very top while most households lose ground threatens to undermine the American Dream and erode the sense that our society gives everyone a fair opportunity to succeed and an equal voice in the nation's future. ${ }^{27}$ By undermining that sense, inequality may harm the morale and work effort of those left behind. ${ }^{28}$

Another problem is political. The wealthiest have a disproportionate influence on public policy. ${ }^{29}$ This gives them an ability and incentive to

Pain, and Worry, Brookings Soc. MoBiLiTy Memos (Feb. 19, 2015, 2:39 PM), http:// www.brookings.edu/blogs/social-mobility-memos/posts/2015/02/19-cost-poverty-stressgraham.

26. See PIKETTY, supra note 19, at 571 (unchecked and growing inequality is "potentially threatening to democratic societies and to the values of social justice on which they are based"); see also Krueger, supra note 24, at 14-17 (surveying objections to inequality based on the enlightened self-interest of members of society in reducing the negative externalities that inequality tends to create, including crime, less-informed political and policy decisions, and the adverse social consequences of poor performance by low-wage workers).

27. See President Barack Obama, Remarks by the President on Economic Mobility (Dec. 4, 2013), available at http://www.whitehouse.gov/the-pressoffice/2013/12/04 /remarks-president-economic-mobility (“[A] dangerous and growing inequality and lack of upward mobility . . . has jeopardized middle-class America’s basic bargain-that if you work hard, you have a chance to get ahead."); see also Thomas Frank, Paul Krugman Won't Save Us: We Need a New Conversation About Inequality, SALON (Feb. 23, 2014, 7:00 AM), http://www.salon.com/chromeo/article/paul_krugman_wont_save_us_we_ need_a_new_conversation_about_inequality ("The word is a polite one, but 'inequality" is what we say when we mean to describe the ruined downtown of your city, or your constant fear that the next round of layoffs will include you, or the impeccable air conditioning of your boss's McMansion, or the way you had to declare bankruptcy when your child got sick.”).

28. See STIGLITZ, supra note 18, at 127-33. See generally Pranab Bardhan, Samuel Bowles \& Herbert Gintis, Wealth Inequality, Wealth Constraints and Economic Performance (Ctr. for Int'l and Dev. Econ. Research, Working Paper No. C98-097, 1999); Shaun P. Hargreaves Heap, Abhijit Ramalingam, Siddharth Ramalingam \& Brock V. Stoddard, Inequality and Effort: An Experiment on Competition Between Teams (Univ. of E. Anglia Ctr. for Behavioural and Experimental Soc. Sci., Working Paper No. 13-08, 2013).

29. See JefFrey A. WinTERS, OligARChy 249 (2011) (“[W]ealthier constituents exert far more influence over government decisions than Americans of modest means, and . . . 
skew public investments and government policies to favor themselves. ${ }^{30}$ These policies also may harm others. ${ }^{31}$ For example, the fundamental short-run policy tradeoff faced by the Federal Reserve is balancing the

the effects of undifferentiated public opinion on decision makers are almost zero.”); MARTin Gilens, AfFluenCE \& INFLUENCE: ECONOMIC INEQUALITY AND POLITICAL POWER IN AMERICA 85 (2012) ("[T]he responsiveness of policy makers to the preferences of the American public is highly skewed in favor of the most affluent . . ..”); see also Larry M. Bartels, Unequal Democracy: The Political Economy of the NeW GILDED AGE 252-83 (2008) (observing that elected officials are unresponsive to the policy preferences of low-income citizens); THOMAS BYRnE EDSALL, THE NEW POLITICS OF INEQUALITY 241-42 (1984) (observing (three decades ago, at the start of the modern surge in inequality) that "pervasive distortions" in the political process have created a system in which fundamental issues are resolved "by an increasingly unrepresentative economic elite" that controls national economic policy "regardless of which party is in control of the federal government”); Martin Gilens \& Benjamin I. Page, Testing Theories of American Politics: Elites, Interest Groups, and Average Citizens, 12 PERSPECTIVES ON POLITICS 564, 576 (2014) (“[T] he preferences of 'affluent' citizens have far more independent impact upon policy change than the preferences of average citizens do.” (internal punctuation omitted)).

30. See STigLiTz, supra note 18, at 36 ("One of the ways that those at the top make money is by taking advantage of their market and political power to favor themselves, to increase their own income, at the expense of the rest.”); see also Barak Orbach, A State of Inaction: Regulatory Preferences, Rent, and Income Inequality, 16 THEORETICAL INQUIRIES IN LAW 45 (2015) (discussing legal policies that accommodate rent extraction); $c f$. Daron ACEMoglu \& James A. Robinson, Why Nations Fail: The Origins of PowER, PROSPERITY, AND POVERTY (2012) (connecting prosperity to inclusive economic and political institutions, as distinct from extractive institutions). See generally STIGLITZ, supra note 18, at 28-51 (chapter on "Rent Seeking and the Making of an Unequal Society”).

31. The disproportionate influence of the wealthy over public policies governing financial institutions may have contributed to macroeconomic instability (bubbles and busts). STIGLITZ, supra note 18, at 131-33; cf. Daron Acemoglu, Economic Power Begets Political Power, ECONOMIST (Jan. 23, 2011, 4:52 PM), http://www.economist.com /economics/by-invitation/guest-contributions/economic_power_begets_political_power (underscoring "a particular connection between inequality and economic instability over [the] last three decades" arising from the political power of the financial industry). Such instability harms economic growth by diverting workers and investment to unproductive sectors during bubbles and by underutilizing willing workers and the capital stock during recessions. Cf. Thomas Philippon, Has the U.S. Finance Industry Become Less Efficient? On the Theory and Measurement of Financial Intermediation, AM. ECON. REV (forthcoming Sept. 2014), available at http://pages.stern.nyu.edu/ tphilipp/research.htm (the finance industry has grown in share of national income without becoming more efficient); Benjamin B. Lockwood, Charles G. Nathanson \& E. Glen Weyl, Taxation and the Allocation of Talent 37 (Apr. 3, 2014) (unpublished manuscript), available at http://ssrn.com /abstract=1324424 (under some assumptions "the worsening allocation of talent in the United States is large enough to account for all of the increase in inequality or nearly half of the fall in growth between the 1948-1973 period and the 1982-2007 period”). 
harms from unemployment against the risks of inflation. The rich have less incentive to favor policies that tilt towards reductions in unemployment relative to prevention of inflation. They are unlikely to become unemployed. And as creditors with some assets denominated in nominal terms, their real wealth is reduced by inflation. ${ }^{32}$ While unemployment reduces demand for the products sold by the firms they own, that harm to the firms is mitigated somewhat by the fact that high unemployment reduces the wage demands of workers. ${ }^{33}$ The middle class and poor, by contrast, are far more likely to experience unemployment or lower wages as the result of a higher unemployment rate. They also are more likely debtors that benefit from inflation.

This political effect can make inequality self-reinforcing: the economic power of those at the top gives the wealthy political power, which can be used to entrench and enhance their economic power, further increase their political power, and so on. This vicious cycle creates the possibility that inequality could threaten our democracy. ${ }^{34}$ This concern is exacerbated by the growing trend to greater social separation by the top earners, through gated communities, private schools, and other privileges. For example, it has long been suggested that private schools reduce political support for larger public school budgets. The same point might be made with respect to public health care and transportation when concierge doctors and express lanes cater to the rich.

Inequality also can reduce economic growth. The economic literature has reached a "tentative consensus" that inequality "tends to reduce the pace and durability of growth." 35 Even a small reduction in the long-term

32. See Matthias Doepke \& Martin Schneider, Inflation and the Redistribution of Nominal Wealth, 114 J. POL. ECON. 1069 (2006) (inflation harms rich, old households owning bonds and benefits young, middle-class households with fixed-rate mortgage debt); see also Paul Krugman, The Deflation Caucus, N.Y. TIMES (Sept. 4, 2014) ("Inflation helps debtors and hurts creditors, deflation does the reverse. And the wealthy are much more likely than workers and the poor to be creditors, to have money in the bank and bonds in their portfolio rather than mortgages and credit-card balances outstanding.”); Paul Krugman, Who Wants a Depression?, N.Y. TIMES (July 10, 2014) (the wealthy favor higher interest rates because they derive an important part of their income from interest on bonds).

33. David G. Blanchflower \& Andrew J. Oswald, An Introduction to the Wage Curve, 9 J. ECON. PERSP. 153 (1995).

34. STIGLITZ, supra note 18 , at 148-82.

35. Jonathan D. Ostry, Andrew Berg \& Charalambos Tsangarides, Redistribution, Inequality, and Growth 4 (Int'l Monetary Fund, Staff Discussion Note, 2014); accord Fed- 
rate of growth makes a substantial difference to economic well-being from one generation to the next. ${ }^{36}$

Inequality can slow economic growth for several reasons. Workers in families experiencing financial hardship may find it difficult to invest in education and training because they lack the necessary savings and because financial market imperfections limit their ability to borrow against their future prospects. ${ }^{37}$ Their incentives to change jobs, learn new skills, or start new businesses also can be reduced. Poverty makes it harder for students to learn, and a majority of the students in public schools today are from low-income families. ${ }^{38}$ Moreover, the disproportionate influence on public policy by those at the very top can lead to insufficient provision of public goods that would disproportionately benefit others, even when those programs foster overall economic growth. These same factors also can contribute to creating a vicious cycle of widening inequality.

We are not claiming that concerns about inequality are ignored in our society. Social insurance programs provide benefits to people who are unemployed, poor, retired and disabled. Government programs support public goods such as health care, education, job training, and housing. While certain redistributive policies may impede growth, ${ }^{39}$ redistribution has

erico Cingano, Trends in Income Inequality and Its Impact on Economic Growth (OECD Social, Employment and Migration Working Papers, Working Paper No. 163, 2014); OECD, Focus on INEQUALITY AND GROWTH: DOES INCOME INEQUALITY HuRT ECONOMIC GROWTH? 2 (2014), available at http://www.oecd.org/els/soc/Focus-Inequalityand-Growth-2014.pdf (estimating that rising inequality over the past quarter century reduced U.S. GDP by 7\% to 8\%); Torsten Persson \& Guido Tabellini, Is Inequality Harmful for Growth? 84 AM. ECON. REV. 600 (1994) (inequality is related to slow growth in democracies); $c f$. ElHANAN HELPMAN, THE MYSTERY OF ECONOMIC GROWTH 93 (2004) (reaching a "tentative conclusion" that "inequality slows growth").

36. DAVID N. WEIL, ECONOMIC GROWTH 12 (2005) (small differences in the rate of growth between the U.S. and U.K. had a large effect on per-capita income over time).

37. See Oded Galor \& Joseph Zeira, Income Distribution and Macroeconomics, 60 REV. ECON. STUD. 35 (1993) (with credit market imperfections and indivisibilities in human capital investment, the distribution of wealth affects aggregate output and investment); $c f$. Thomas Piketty, The Dynamics of the Wealth Distribution and the Interest Rate with Credit Rationing, 64 REV. ECON. STUD. 173 (1997) (with credit-rationing, short-run shocks to the income distribution have long-run effects on output).

38. Steve Suitts, Southern Education Foundation, A New Majority: Low InCOME STUDENTS NOW A MAJORITY IN THE NATION'S Public SCHOOLS (2015), available at http://www.southerneducation.org/Our-Strategies/Research-and-Publications/NewMajority-Diverse-Majority-Report-Series/A-New-Majority-2015-Update-Low-IncomeStudents-Now.

39. See Arthur M. Okun, Equality and Efficiency: The Big Tradeoff 91-95 
generally not done so in practice. ${ }^{40}$ Instead, these programs have been found to encourage economic growth, even when they are funded in ways that redistribute resources away from those at the top. ${ }^{41}$ Despite these benefits from redistribution, existing programs do not appear to have offset the growing inequality in our economy.

\section{MARKET POWER AND OTHER CAUSES OF INEQUALITY}

Researchers have identified a number of factors that likely have contributed to the recent growth in U.S. inequality. ${ }^{42}$ Globalization has allowed lower-wage workers abroad to compete down domestic manufacturing wages-for example, by off-shoring high-wage manufacturing jobs. Technological change has generated large fortunes for the owners of many of the most successful firms. Labor-saving technologies also are shifting income away from lower-level workers to owners of capital. This also contributes to less job security and a higher unemployment rate, both of which reduce the bargaining power of workers in wage negotiations. A less hospitable economic and regulatory climate for labor unions and erosion of the purchasing power of the minimum wage also have shifted income from workers to stockholders. Changes in corporate governance have contributed to top executives obtaining larger compensation packages. ${ }^{43}$ Decreased collection of federal estate taxes also may be a factor. ${ }^{44}$

(1975) (characterizing redistributive policies as a "leaky bucket”); Persson \& Tabellini, supra note 35 (inequality exacerbates distributional conflicts in democratic polities, leading to the adoption of the types of redistributive policies that discourage private investment); Alberto Alesina \& Dani Rodrik, Distributive Politics and Economic Growth, 109 Q. J. ECON. 465 (1994) (same).

40. See Ostry, Berg \& Tsangarides, supra note 35, at 7, 26.

41. See generally Ostry, Berg \& Tsangarides, supra note 35. Redistribution does not impede growth if it appropriates economic rents of those at the top without reducing the marginal benefits to work and investment, and it can stimulate growth if the resources are used to fund highly productive public or private investments. If those resources are used to improve the skills, education, and health of the bottom $40 \%$, for example, they can increase growth as well as social mobility. See Rebecca M. Blank, Can Equity and Efficiency Complement Each Other? 9 LABOUR ECON. 451 (2002); Karla Hoff \& Andrew B. Lyon, Non-Leaky Buckets: Optimal Redistributive Taxation and Agency Costs, 58 J. PuB. ECON. 365 (1995); $c f$. LOUIS KAPLOW, THE THEORY OF TAXATION AND PUBliC ECONOMICS 116-19 (2010) (discussing efficiency justifications for some redistributive taxation).

42. See generally STIGLiTZ, supra note 18, at 35-103; Alvaredo et al., supra note 8.

43. See generally Lucian BebchuK \& Jesse Fried, Pay Without Performance: THE UNFUlFILLED PROMise OF EXECUTIVE COMPENSATION (2004). 
Financial deregulation and other policy changes have contributed to huge increases in top-end incomes, often while shifting risks to the public of the type illustrated by the consequences of the 2008 financial meltdown.

Market power also contributes to growing inequality. Technological change has created more markets with intellectual property protection or network effects, which can permit firms to achieve market power. Microsoft, Oracle, Google, Facebook, and Bloomberg, for example, may have obtained the ability to exercise market power in some of their major markets during the past quarter century in this way. ${ }^{45}$ The adoption of more permissive antitrust rules during the past quarter century has also likely increased the prevalence of market power. ${ }^{46}$ The returns from market power go disproportionately to the wealthy-increases in producer surplus from the exercise of market power accrue primarily to sharehold-

44. Dylan Mathews, No One Pays the Estate Tax, WASH. Post WonkBLOG (July 26, 2012), http://www.washingtonpost.com/blogs/wonkblog/wp/2012/07/26/no-one-pays-the -estate-tax.

45. Market power contributes to inequality even if it is achieved and exercised legitimately. (As far as we know, Microsoft is the only firm among those listed that has been found by U.S. courts to have violated the antitrust laws.) $C f$. Fiona Scott-Morton, Deputy Assistant Attorney Gen., Antitrust Div., U.S. Dep't of Justice, Remarks at the 2012 NYSBA Annual Antitrust Forum: Antitrust Enforcement in High-Technology Industries: Protecting Innovation and Competition 6 (Dec. 7, 2012), available at http://www.justice .gov/atr/public/speeches/290876.pdf (observing that "high-tech industries often have large supply-side and demand-side economies of scale” which can lead one or more firms "to rapidly obtain and sustain a significant market share that can be hard to reverse"). We chose these innovative late-twentieth-century information technology firms to illustrate the possibility of market power fostered by intellectual property protections or network effects because these companies' founders (or founders' heirs) appear among the top twenty wealthiest Americans listed by Forbes. See Forbes 400: The Richest People in America, FORBES, http://www.forbes.com/forbes-400 (last visited Apr. 8, 2015). Other potential sources of market power suggested by the business models of firms associated with names among the top twenty include economies of scale (Walmart and Amazon) and product differentiation (Mars and Nike). These nine firms account for fifteen of the fortunes represented by the top twenty entries on the Forbes 400 list. Id. (We have not attempted to provide an exhaustive list of ways of obtaining market power. Other possibilities, which do not necessarily apply to the firms we have mentioned, include government grants (beyond intellectual property rights), predatory conduct, collusive conduct, and merger.)

46. See Jonathan B. Baker, Economics and Politics: Perspectives on the Goals and Future of Antitrust, 81 FORDHAM L. REV. 2175, 2184 (2013) (observing that modifications to antitrust rules during the 1980s, introduced to address Chicago school arguments that the prior rules were chilling production efficiencies, likely "tended to redistribute surplus from consumers to large firms by increasing the risk that firms will exercise market power"). 
ers and the top executives, who are wealthier on average than the median consumer. ${ }^{47}$ Unionized workers historically may also have been able to appropriate some market power rents, but this possibility has limited practical importance today with the decline of private sector unionization.

Thomas Piketty's suggestion that capitalist economies tend toward inequality in the long run when the return to capital exceeds the economy's growth rate ${ }^{48}$ also connects market power with inequality. The exercise of market power tends to raise the return to capital, increasing the divergence between that return and the rate of economic growth. By discouraging innovation and productivity on balance, ${ }^{49}$ moreover, market power also will

47. See Wolff, supra note 3, at 38 tbl.7 (as of 2013, the top 1\% of the wealth distribution hold $49.8 \%$ of stock and mutual fund assets, and the top 10\% hold $90.9 \%$; if indirect ownership through retirement plans and similar accounts is taken into account, the top $10 \%$ own $81.4 \%$ of those assets). The top $10 \%$ also own $93.8 \%$ of unincorporated business equity. Id. Consistent with this view, in 1975 William Comanor and Robert Smiley concluded that market power mainly augments the wealth of the wealthiest households and thus has had "a major impact on the degree of [wealth] inequality" in the U.S. William S. Comanor \& Robert H. Smiley, Monopoly and the Distribution of Wealth, 89 Q. J. ECON. 177, 189 (1975). Comanor and Smiley's study is not conclusive, however, as their calibration calculations are sensitive to the assumption they make about the extent of market power in the economy; their model is not fully specified, as it treats the total profits from the exercise of market power as independent of the length of time that market power is exercised, and it is unlikely that even the most aggressive antitrust enforcement would prevent every exercise of market power.

48. PIKETTY, supra note 19, at 1 ("When the rate of return on capital exceeds the rate of growth of output and income, as it did in the nineteenth century and seems quite likely to do again in the twenty-first, capitalism automatically generates arbitrary and unsustainable inequalities that radically undermine the meritocratic values on which democratic societies are based.”); cf. Thomas Piketty, About Capital in the 21st Century, AM. ECON. REV. (forthcoming May 2015) (a higher gap between the rate of return on capital and rate of economic growth "works as an amplifier mechanism for wealth inequality, for a given variance of other shocks”). Piketty notes that redistributive social policies and outside forces like war, depression, and technological change can mitigate the tendency toward inequality he identifies. Lawrence Summers catalogues other reasons to question the dynamic Piketty emphasizes. See Summers, supra note 20, at 94-96.

49. See generally Jonathan B. Baker, Beyond Schumpeter vs. Arrow: How Antitrust Fosters Innovation, 74 ANTITRUST L.J. 575, 583-86 (2007); Nicholas Bloom \& John Van Reenen, Why Do Management Practices Differ Across Firms and Countries? 24 J. ECON. PERSP. 203, 215 (2010) (competitive product markets foster better management and improved productivity by speeding the exit of poorly performing firms and strengthening firm incentives to improve management practices); Carl Shapiro, Competition and Innovation: Did Arrow Hit the Bull's Eye?, in THE RATE AND DIRECTION OF INVENTIVE ACTIVITY REVISITED 361, 376-82 (Josh Lerner \& Scott Stern eds., 2012); $c f$. Steven C. Salop, Question: What Is the Real and Proper Antitrust Welfare Standard? Answer: The True Consumer Welfare Standard, 22 LOY. CONSUMER L. REV. 336, 349-50 (2009) (in 
tend to slow the rate of economic growth, ${ }^{50}$ further increasing the divergence.

A range of factors have contributed to growing inequality. While other factors may play a greater role, market power likely has an effect. Because the creation and exercise of market power tend to raise the return to capital, market power contributes to the development and perpetuation of inequality. As market power grows more common and visible, increasing public concern with inequality may call for a competition policy response.

\section{Using ANTITRUST AND COMPETITION POLICY TO RESPOND TO INE- QUALITY CONCERNS}

Effectively responding to inequality concerns would require a concerted effort across a wide range of public policies. A number of commentators have called on competition policy specifically to address inequality. ${ }^{51}$

the absence of competition, society cannot rely on diffusion of innovation across firms to ensure that those innovations benefit consumers).

50. For the same reason, consumers do not benefit on average in the long run from the exercise of market power, through what is sometimes termed "dynamic competition," even if firms reinvest the resulting producer surplus in efforts to lower their costs and improve their products. See Jonathan B. Baker, "Dynamic Competition" Does Not Excuse Monopolization, 4 COMPETITION POL'Y INT'L 243 (2008).

51. See, e.g., STIGLITZ, supra note 18, at 338 (calling for "stronger and more effectively enforced competition laws" to help address inequality); DEAN BAKER, CENTER FOR ECONOMIC AND POLICY RESEARCH, LIVING IN THE SHORT-Run: COMMENT ON CAPITAL IN THE 21ST CENTURY 5 (2014) (pointing to "large sectors of the economy where textbook regulation of monopolies or old-fashioned anti-trust actions may have a substantial impact on industry profits" and thereby limit inequality, such as the cable and telephone industries); Sandeep Vaneesan, The Evolving Populisms of Antitrust, 93 NEB. L. REv. 370, 409-14 (2014) (arguing that consumer-oriented antitrust enforcement can promote more progressive wealth distribution); Steven Davidoff Solomon, Changing Old Antitrust Thinking for a New Gilded Age, N.Y. Times DEALBOOK (July 22, 2014, 8:56 PM), http://dealbook.nytimes.com/2014/07/22/changing-old-antitrust-thinking-for-a-new-

gilded-age (calling for reforms to the antitrust laws to address the economic and political power of oligopolies); Shi-Ling Hsu, The Rise and Rise of the One Percent: Getting to Thomas Piketty's Wealth Dystopia 29 (Aug. 9, 2014) (unpublished manuscript), available at http://works.bepress.com/cgi/viewcontent.cgi?article=1033\& context=shi_ling_hsu (favoring "a more conscious comparison of the impacts of antitrust policy on returns to private capital and on economic growth"); $c f$. LUIGI ZINGALES, A CAPITALISM FOR THE People: Recapturing the Lost Genius of AMERICAN PRosPerity (2012) (the "most powerful argument for antitrust law" is that it "reduces the political power of firms"); Barry C. Lynn, Killing the Competition: How the New Monopolies are Destroying Open Markets, HARPER's MAG., Feb. 2012, at 27, 32 (attributing the growth of market concen- 
Concerns with inequality can implicate antitrust and competition policy in two general ways. First, in that market power contributes to inequality, more aggressive antitrust enforcement might play a remedial role. Second, antitrust enforcers and regulatory agencies such as the Federal Communications Commission (FCC) might make reducing the effects of inequality a high priority in developing enforcement and regulatory initiatives. Distributional effects already are taken into account to some extent today. If inequality gains prominence on the political agenda, there might be greater demand for these policies.

The remainder of this article identifies a number of specific antitrust and competition policy approaches and adjustments in legal standards that might be considered by policy makers in response to increasing public concern with inequality. Some of the proposals target primarily the exercise of market power as a source of inequality, while others emphasize treating a reduction in inequality as an explicit competition policy goal.

The proposals differ in a variety of ways. As indicated by our discussion, some of the proposals would make more of a difference than others, and some would be easier to implement in practice than others. The greater the public concern about inequality and the greater the incidence of market power, moreover, the more likely that one would see policy changes being suggested that extend beyond those that can be adopted under current law, and the more likely those policy changes could be justified. These could include policies that would require the courts to adjust legal standards or Congress to undertake legislative action. The proposals towards the end of the list are generally broader and more controversial than the earlier ones. We would expect that policy makers would not propose the latter ones lightly, and would become more likely to consider them as their concerns about inequality increase. We recognize that some of these policies would be highly controversial, and we set them out here in order

tration and market power across the U.S. economy to the acceptance of Chicago School arguments privileging economic efficiency as the goal of antitrust policy); Lina Khan and Sandeep Vaheesan, How America Became Uncompetitive and Unequal, WASH. PosT (June 13, 2014), http://www.washingtonpost.com/opinions/how-america-becameuncompetitive-and-unequal/2014/06/13/a690ad94-ec00-11e3-b98c-72cef4a00499_story. html ("The lack of competition in many sectors of the U.S. economy is . . . a powerful driver of economic disparity.”). But see Daniel Crane, Antitrust and Inequality (Feb. 3, 2015) (unpublished manuscript) (on file with authors) (questioning the use of antitrust to address inequality). We address some of our disagreements with Professor Crane's conclusions below. 
to clarify the issues they raise and frame further discussion.

\section{A. REJECTING ARGUMENTS TO ABANDON THE CONSUMER WELFARE STAND-}

ARD

The modern Supreme Court has adopted an exclusively economic approach to interpreting the antitrust laws, rejecting social and political goals that were important to antitrust in the past. ${ }^{52}$ In contemporary academic writing, the debate over goals often is framed as a choice between two overarching economic standards: the consumer welfare standard (in the sense of consumer surplus) and the aggregate economic welfare standard (in the sense of total surplus, regardless of distributional consequences). ${ }^{53}$ These approaches also could be fine-tuned by using a weighted average of consumer surplus and producer surplus, where the weights depend on particular distributional goals. ${ }^{54}$

Judges are less interested than commentators in debating the appropriate welfare standard. In practice, the courts consistently employ a consumer welfare test. ${ }^{55}$ Judicial acceptance of this standard also has been sup-

52. See generally Baker, supra note 46, at 2178.

53. Some authors instead view the goal of antitrust as protection of the competitive process generally. See Eleanor M. Fox \& Lawrence A. Sullivan, Antitrust-Retrospective and Prospective: Where Are We Coming From? Where Are We Going? 62 N.Y.U. L. REV. 936, 936 (1987); Gregory J. Werden, Antitrust's Rule of Reason: Only Competition Matters, 79 ANTITRUST L.J. 713, 737, 756-59 (2014); see also Joseph Farrell \& Michael L. Katz, The Economics of Welfare Standards in Antitrust, 2 COMPETITION POL'Y INT'L 3, 5-9 (2006) (antitrust is concerned with both process and outcomes). Moreover, some commentators advocate what have been referred to as "non-economic" goals. See, e.g., Neil W. Averitt \& Robert H. Lande, Using the "Consumer Choice" Approach to Antitrust Law, 74 ANTITRUST L.J. 175 (2007) (consumer choice); Richard M. Brunell, The Social Costs of Mergers: Restoring "Local Control" as a Factor in Merger Policy, 85 N.C. L. REV. 149 (2006) (local community ties); Harry First \& Spencer Weber Waller, Antitrust's Democracy Deficit, 81 Fordham L. REV. 2543, 2545 (2013) (democratic decision-making); Stephen F. Ross, Network Economic Effects and the Limits of GTE Sylvania's Efficiency Analysis, 68 ANTITRUST L.J. 945 (2001) (equal economic opportunity); Maurice E. Stucke \& Allen P. Grunes, Antitrust and the Marketplace of Ideas, 69 ANTITRUST L.J. 249 (2001) (diversity of voices).

54. See, e.g., Gary L. Roberts \& Steven C. Salop, Efficiencies in Dynamic Merger Analysis, 19 WORLD COMPETITION 5, 12 (1996) (applying a standard that weights consumer and producer welfare, with weights that depend on social preferences); Louis Kaplow, On the Choice of Welfare Standards in Competition Law 6 (Harvard John M. Olin Center for Law, Economics, and Business, Discussion Paper No. 693, 2011).

55. See Herbert Hovenkamp, Implementing Antitrust's Welfare Goals, 81 FORDHAM L. REV. 2471, 2476 (2013). "Indeed, one is hard pressed to find a single appellate decision 
ported on a number of policy grounds not related directly to distributional concerns. These reasons include its being more readily administrable, ${ }^{56}$ more likely to enhance aggregate welfare given information asymmetries between firms and antitrust enforcers, ${ }^{57}$ and more likely to engender political support. ${ }^{58}$

The consumer welfare standard also helps address inequality because it does not permit conduct that would harm consumers while benefiting shareholders. ${ }^{59}$ In contrast, the aggregate welfare standard can contribute to inequality by permitting conduct that leads to the creation and exercise of market power, if there are also cost savings or other efficiencies associated with the conduct and they are not shared with buyers. Under those circumstances, market power increases producer surplus that accrues primarily to shareholders and top executives, who typically are wealthier than the consumers of the products.

Protecting buyers and their consumer surplus is not identical to pre-

that made [a] finding of fact that a challenged practice resulted in lower market-wide output and higher prices but that also went on to approve the restraint because proven efficiencies exceeded consumer losses." Id.; accord Einer Elhauge, Tying, Bundled Discounts, and the Death of the Single Monopoly Profit Theory, 123 HARV. L. REV. 397, 435-39 (2009); Salop, supra note 49, at 338-48. During the 1980s, many antitrust rules changed in ways recommended by Chicago School commentators who also advocated an aggregate welfare standard, including Robert Bork. But the courts apply the new rules with reference to a consumer welfare goal.

56. See Hovenkamp, supra note 55, at 2477.

57. See David Besanko \& Daniel F. Spulber, Contested Mergers and Equilibrium Antitrust Policy, 9 J.L. ECON. \& ORG. 1 (1993); Joseph Farrell, Negotiation and Merger Remedies: Some Problems, in MERger REMEDIES IN AMERICAN AND EUROPEAN COMPETITION LAW 95 (Francois Leveque \& Howard Shelanski eds., 2003); Damien J. Neven \& Lars-Hendrik Röller, Consumer Surplus vs. Welfare Standard in a Political Economy Model of Merger Control, 23 INT'L J. InDUS. ORG. 829 (2005); Sven-Olof Fridolfsson, A Consumer Surplus Defense in Merger Control (Research Inst. of Indus. Econ., Working Paper No. 686, 2007); see also Farrell \& Katz, supra note 53, at 12-27 (antitrust applications of the observation that in a multi-layered decision process, the individual participants may adopt objectives that differ from those of the system as a whole).

58. See Jonathan B. Baker, Competition Policy as a Political Bargain, 73 ANTITRUST L.J. 483, 521-22 (2006); Baker, supra note 46, at 2186.

59. The direct distributional focus of the consumer welfare standard is limited to the welfare of buyers in a partial equilibrium context. It distinguishes between buyers and producers as groups, but it does not differentiate among buyers by their wealth and treats the buyers of an intermediate good as standing in for end-use consumers. See Baker, supra note 46, at 2176 n.5, 2178 n.9. If tax policy were based on perfect information and individually tailored, then antitrust could maximize total surplus and the IRS could redistribute the market power gains. However, this does not seem feasible, let alone practical. 
venting wealth transfers to those at the top of the wealth distribution. ${ }^{60}$ Application of a consumer welfare standard in principle could increase inequality in matters where consumers tend to be wealthy and the sellers are small firms owned by middle-class entrepreneurs, such as hypothetical cartels among worker-owned manufacturers of luxury goods like fine crystal products or yachts. However, we expect those situations are rare. Overall, therefore, the continued application of a consumer welfare standard likely would lead to less inequality than a change to reliance on an aggregate economic welfare standard. ${ }^{61}$

Continued reliance on the consumer welfare standard will not require any changes in the law. However, some contemporary commentators continue to advocate for an aggregate welfare standard, and this debate could someday influence decisions taken by the antitrust enforcement agencies and the courts. ${ }^{62}$ For this reason, ending the debate with a full embrace of

60. See Farrell \& Katz, supra note 53, at 11 (“Consumer surplus can provide a very poor approximation to a welfare measure that weights impacts using ordinary notions of distributional preferences.”); $c f$. Kaplow, supra note 54, at 5 (on average, the benefits of competitive pricing tend to be proportional to consumption, which rises less than proportionately with income, though not to a huge extent, so "raising consumer welfare across the board certainly generates far greater gains to those who are economically better off”).

61. Professor Crane observes that antitrust violations sometimes benefit the less well off. Crane, supra note 51, at 2, 7-8. He says that it is "not hard to imagine" circumstances in which producers are less well off than consumers. Id. at 14. However, in our experience, antitrust violations rarely involve the sole proprietors and small businesses that Crane mentions when speculating about this possibility. Moreover, when firms exercise market power, it is unlikely that the blue-collar workers and mid-level managers he also references will be able to appropriate much of the resulting profits. Collective bargaining among non-unionized low-wage service workers theoretically might present another example in which cartel enforcement would worsen inequality. But, with the decline of private sector unionization, it is unlikely that workers would appropriate much of the gains from the exercise of market power by their employers; and even if they did, such benefits to employed workers could be offset by the cost to other workers that are laid off or not employed as a result of a reduction in industry output. Unless the firms are workerowned, or the firms sell goods and services purchased only by the wealthiest households, such as yachts or fine crystal, it is hard to be confident that customers would have higher incomes than shareholders. All in all, the typical antitrust violation likely transfers income and wealth to favor those already well off. However, to the extent that antitrust law and policy treat reduction of inequality as a goal, then anticompetitive conduct by the less well off that extracts wealth from the rich might not be condemned, as discussed infra section III.G.

62. Compare Charles F. Rule, Consumer Welfare, Efficiencies, and Mergers, Statement for the Hearing of the Antitrust Modernization Commission (Nov. 17, 2005), available at http://govinfo.library.unt.edu/amc/commission_hearings/pdf/Statement-Rule.pdf (defending aggregate welfare standard), and Ken Heyer, Welfare Standards and Merger 
the consumer welfare standard, based on concerns about the distribution of income and wealth, would be expected to calibrate antitrust standards so they do not promote inequality.

\section{B. INCREASING AGENCY ANTITRUST BUDGETS}

Greater antitrust enforcement generally would improve the distribution of income and wealth by reducing the impact of market power, particularly if the agencies fully embrace the consumer welfare standard. But federal and state antitrust enforcement today is limited by agency budgets. Because every enforcement action has an opportunity cost, the agencies limit the intensity of their enforcement efforts and have to pick and choose which matters to pursue. They similarly are constrained in their ability to litigate multiple cases against deep-pocketed defendants, which may lead them to accept weaker settlements. Private plaintiffs add additional enforcement capacity, but they cannot employ the investigative tools available to the government, so they have less ability to uncover and challenge many types of anticompetitive conduct. If federal and state agency antitrust budgets were increased, the agencies could do more to protect consumers and reduce inequality, even without any changes in antitrust law. Although this proposal would need to compete for scarce tax dollars with other policies for combating income and wealth inequality, it may be more feasible politically to increase antitrust budgets than to adopt policy alternatives incorporating more direct redistribution. In addition, even a modest increase in those budgets may have beneficial effects on deterrence.

\section{EXERCISING PROSECUTORIAL DISCRETION TO PRIORITIZE CASES THAT BENEFIT THE MIDDLE CLASS AND THE LESS ADVANTAGED}

Agency antitrust enforcement could account for inequality concerns by systematically directing resources towards products purchased by middleand lower-class consumers. Under this approach, greater efforts could be devoted to investigating concerns in markets such as food manufacturing and retailing, fuel, and healthcare products. For example, a 1985 study concluded that in forty-five broadly defined food industries, the exercise

Analysis: Why Not the Best?, 2 COMPETITION POL’y INT’L 29 (2006) (same), with Russell Pittman, Consumer Surplus as the Appropriate Standard for Antitrust Enforcement, 3 COMPETITION POL'y INT'L 205 (2007) (defending consumer welfare standard). See generally Symposium, The Goals of Antitrust, 81 FordHAm L. REV. 2151 (2013). 
of market power led prices to rise more for low-income households than for high-income households in all but nine industries. ${ }^{63}$ A greater focus could also be given to concerns about monopsony power exercised against workers and small businesses.

We do not intend to criticize the enforcement agencies. To a noticeable extent, this policy focus is implemented today. ${ }^{64}$ However, the approach could be given more emphasis and coupled with expanded budgets. In addition, the agencies might forgo using scarce agency resources for matters where the bulk of harms are suffered by the rich. ${ }^{65}$ In their prosecutorial discretion, the agencies also might attach lower priority to enforcement

63. For those nine, the incidence was similar across income groups. John M. Connor, Richard T. Rogers, Bruce W. Marion \& Willard F. Mueller, THE FoOD MANUFACTURING Industries: Structure, Strategies, Performance, AND Policies 341 tbl.D-5 (1985); cf. id. at 297-98 ("There are a number of foods for which reductions in monopoly pricing would effectively raise the incomes of the poor at twice the rate of the rich; examples include processed meats, fluid milk, canned vegetables, flour, rice, sugar, soft drinks, and margarine.”).

64. See, e.g., Complaint, In re South Carolina State Bd. of Dentistry, No. 9311 (F.T.C. Sept. 15, 2003) (charging that anticompetitive conduct led to fewer children-particularly economically disadvantaged children-receiving preventive dental care in schools). The Federal Trade Commission's budget justification for 2016 highlights antitrust enforcement and advocacy efforts in energy, healthcare, and supermarket retailing — all sectors in which enforcement may benefit the disadvantaged disproportionately. FED. TRADE COMM'N, FY 2016 CONGRESSIONAL BUDGET JUSTIFICATION 18-24, available at https://www.ftc.gov/system/files/documents/reports/fy-2016-congressional-budget-

justification/2016-cbj.pdf. In the U.S., as well as in developing nations, moreover, antitrust enforcement efforts against collusion in public procurement likely benefit the economically disadvantaged. See generally Robert D. Anderson \& William E. Kovacic, Competition Policy and International Trade Liberalisation: Essential Complements to Ensure Good Performance in Public Procurement Markets, 18 PuB. Procurement L. REV. 67 (2009); William E. Kovacic, Competition Policy, Consumer Protection, and Economic Disadvantage, 25 J. L. \& POL’Y 101 (2007).

65. See, e.g., Polygram Holding, Inc. v. FTC, 416 F.3d 29, 36 (D.C. Cir. 2005) (successful FTC challenge to collusive restrictions on advertising opera concert recordings). A 1992 study found that opera audiences are disproportionately wealthy, and opera recordings are likely purchased disproportionately by a similar demographic. JONI MAYA Cherbo \& Monnie PETERs, NAT'L Endowment FOR the ARTS, AMERICAN PARTiCiPATION IN OPERA AND MUSICAL THEATER, 1992, at 22-23 (1995) available at http://arts.gov /publications/american-participation-opera-and-musical-theater-1992. See also United States v. Gillette Co., 828 F. Supp. 78 (D.D.C. 1993) (unsuccessful Department of Justice challenge to merger among sellers of premium fountain pens, which are likely purchased disproportionately by the well-to-do). Professor Crane points to allegations of antitrust violations leading to higher prices for products sold primarily to the wealthy in markets such as gem-quality diamonds, stock brokerage services, auctioning of high-end art, luxury automobiles, and skiing. Crane, supra note 51, at 8. 
against allegedly anticompetitive conduct that likely benefits the disadvantaged. ${ }^{66}$ For example, the agencies might consider forgoing a hypothetical case involving concerted monopsony conduct by organizations to negotiate lower interest rates from sellers of payday loans. ${ }^{67}$ These actions would not require a change in antitrust law.

\section{DESIGNING REMEDIES TO BENEFIT LESS ADVANTAGED CONSUMERS}

Within current antitrust law, inequality might be addressed in individual cases by adopting remedies designed primarily to benefit less advantaged consumers. For example, this might involve divestitures or price caps placed on certain products and technologies targeted at less advantaged buyers. For example, a drug merger might be permitted if the merged firm were to commit to low-price distribution of the product to patients with lower-quality insurance coverage. Regulatory agencies could do the same. For example, the FCC conditioned its approval in 2011 of Comcast's NBCU acquisition on Comcast's commitment to subsidize broadband to low-income buyers. ${ }^{68}$

This policy would not require accounting for distribution in determining whether the antitrust laws were violated. Instead, in specific cases where violations have been demonstrated, courts and agencies would use existing remedial tools to ensure that the distributional effects reduce inequality, which will also help deter anticompetitive conduct in other markets that target the less well off. For example, the Department of Justice might pursue stronger remedies (higher fines and longer executive prison sentences) when firms fix the prices of products purchased by lowerincome consumers. Of course, such remedial actions would be predicated

66. See, e.g., FTC v. Superior Ct. Trial Lawyers Ass'n, 493 U.S. 411 (1990) (collusive group boycott among court-appointed counsel for indigent defendants). Professor Crane has suggested that the agreement challenged in the Ivy League financial aid price-fixing case might have benefitted the poor. Crane, supra note 51, at 18-19 (discussing United States v. Brown Univ., 5 F.3d 658 (3d Cir. 1993)). That conclusion is debatable, however, as the challenged agreement likely reduced financial aid to highly talented poor students and it may have allowed the colleges to reduce their overall financial aid budgets.

67. Resource allocation decisions would also involve considerations such as the benefits of deterring similar anticompetitive conduct in other markets. The high value of establishing a precedent also might sometimes lead enforcers to pursue cases against sympathetic parties. However, the cost to inequality from doing so should be recognized.

68. Applications of Comcast Corp., Gen. Elec. Co. \& NBC Universal, Inc. for Consent to Assign Licenses \& Transfer Control of Licensees, 26 FCC Rcd. 4238, 4242 (2011). 
on whether the agencies and courts can target less affluent consumers, which would need to take into account the potential for resale. In addition, when a case presents multiple remedial options or the possibility of benefitting multiple disadvantaged groups, courts and agencies would need to develop a principled basis for allocating limited remedial resources.

\section{E. REBALANCING TOWARDS MORE INTERVENTIONIST ANTITRUST AND REGU- \\ LATORY STANDARDS}

The formulation of legal standards strikes a balance between the cost of under-deterrence versus over-deterrence of conduct that would achieve, maintain, or enhance market power. ${ }^{69}$ But the Supreme Court has recently been shifting that balance by making it more difficult to prove meritorious cases. While raising concerns about false positives, the Court has not analyzed the incidence and consequences of false positives, nor compared the resulting costs with the social benefits of antitrust enforcement or the incidence and consequences of false negatives and under-deterrence. ${ }^{70}$ If growing concerns about inequality lead to the recognition that there are additional harms from market power, that recognition would justify reconsideration of the balance and the adoption of more interventionist antitrust rules.

This policy adjustment would not require new legislative action. It would be implemented in the agencies through case selection decisions that place more weight on deterring the exercise of market power relative to concerns about over-deterrence. It would be implemented in the courts through a common law approach that simply recognizes greater harm from market power than previously has been identified. ${ }^{71}$ This type of policy

69. We have each written about the proper application of the decision-theoretic framework to antitrust. See Jonathan B. Baker, Taking the Error Out of "Error Cost" Analysis: What's Wrong with Antitrust's Right, 80 ANTITRUST L.J. (forthcoming 2015); C. Frederick Beckner III \& Steven C. Salop, Decision Theory and Antitrust Rules, 67 ANTITRUST L.J. 41, 43-52 (1999).

70. Baker, supra note 69, at pt. II.B.4.

71. Antitrust commentary suggests various specific ways to strengthen enforcement that might be considered, including: greater attention to exclusionary conduct, more relaxed standards for inferring agreement, more aggressive merger enforcement, stronger remedies against cartel behavior, greater use of divestiture remedies in monopolization cases, increased concern with attempts to monopolize by firms with non-dominant market shares, reinvigorating the essential facilities doctrine, reversing the recent trend in the Supreme Court of raising procedural barriers to private antitrust cases (which also adversely affect public enforcement), and reviving the Federal Trade Commission's 
adjustment also might be implemented by the Federal Trade Commission under its statute. ${ }^{72}$

Competition policy outside of antitrust similarly could be strengthened. Possibilities might include removing regulatory impediments to competition, ${ }^{73}$ reducing regulatory capture by incumbent firms seeking protection from competition, ${ }^{74}$ and clarifying the scope of uncertain intellectual property rights by reducing their breadth. ${ }^{75}$ The federal antitrust agencies would continue to participate in this process with their regulatory intervention programs, while advocating policy changes that would give inequality concerns greater weight.

\section{F. RECOGNIZING EXCESSIVE PRICING BY DOMINANT FIRMS AS AN ANTITRUST} OFFENSE

The monopolization offense generally requires that firms with monopoly power also have engaged in exclusionary conduct to achieve, maintain, or enhance that power. ${ }^{76}$ If a firm achieves monopoly power solely through superior efficiency, skill, or luck, it generally does not violate the Sherman Act merely by exploiting that market power to charge supracompetitive prices. U.S. antitrust law could do more to address inequality if the antitrust laws also addressed monopolistic "exploitative” conduct

dormant competition rulemaking power.

72. Steven C. Salop, Guiding Section 5: Comments on the Commissioners (Nov. 2, 2013) (unpublished manuscript), available at http://scholarship.law.georgetown.edu /facpub/1275.

73. See generally Aaron Edlin \& Rebecca Haw, Cartels by Another Name: Should Licensed Occupations Face Antitrust Scrutiny? 162 U. PENN. L. REV. 1093 (2014). But cf. Baker, supra note 46, at 2191 (much of the low-hanging fruit from deregulation has been captured; additional deregulation in many industries would risk threatening competition).

74. See generally PREVENTING REgUlatory CAPTURE: SPECIAL INTEREST INFLUENCE AND How TO LiMIT IT (Daniel Carpenter \& David A. Moss eds., 2013).

75. See generally ADAM B. JAFFE \& JOSH LERNER, INNOVATION AND ITS DISCONTENTS: HOW OUR BROKEN PATENT SySTEM IS ENDANGERING INNOVATION AND PROGRess, AND What to Do About It (2004); $c f$. James Bessen \& Michael J. Meurer, Patent Failure: How Judges, Bureaucrats, and Lawyers Put InNovators at RISK (2008) (calling for policy changes to improve notice about the scope of patent rights).

76. In contrast, Professor Elhauge argues that exploiting the monopoly power by tying and raising the price of the tied product would violate the Sherman Act. Elhauge, supra note 55, at 421-26 (the Supreme Court objects to tying in part because that practice allows the extraction of individual consumer surplus); see also id. at 407-13, 435 (discussing harms from extraction of individual consumer surplus). 
along the lines of the European prohibition against abuse of dominance. ${ }^{77}$ If pursued under the Sherman Act, such a change in policy toward monopoly conduct might require legislative action.

This policy also might be implemented today by the Federal Trade Commission under its existing statute. The FTC could conclude that monopoly pricing or price discrimination targeted at less advantaged consumers can be an unfair practice in violation of Section 5 of the Federal Trade Commission Act, even if the market power was legitimately obtained. While the scope of that statute is disputed, it is well established that the FTC Act reaches unfair conduct that goes beyond the four corners of the Sherman Act. ${ }^{78}$ In the current environment, of course, taking this step would be considered a controversial action by the FTC, in part because of a reluctance to commit agency resources to ongoing regulatory supervision of dominant firm prices and a concern that doing so could subject the agency to legislative demands to cap the prices charged by large firms in a range of industries. ${ }^{79}$

A much more extreme implementation of such concerns would involve a return to the ideas of no-fault monopoly and oligopoly, ${ }^{80}$ which were discussed but rejected in the 1960s. ${ }^{81}$ However, the concerns about distorting the conduct of firms on the verge of reaching the trigger for breakup and about the loss of scale economies from implementing such a

77. See Miguel de la Mano, Renato Nazzini \& Hans Zenger, Article 102, in THE EU LAW OF COMPETITION 329, § 4.825 (Jonathan Faull \& Ali Nikpay eds., 3d ed. 2014) ("[T] he prevailing view is that Article 102 is expressly concerned with a dominant firm's ability to exploit consumers, including by charging them unfairly high prices ....”).

78. See FTC v. Indep. Fed'n of Dentists, 476 U.S. 447, 454 (1986); FTC v. Sperry \& Hutchinson Co., 405 U.S. 233, 244 (1972); FTC v. Brown Shoe Co., 384 U.S. 316, 32021 (1966); FTC v. Motion Picture Adver. Serv. Co., 344 U.S. 392, 394-95 (1953).

79. Excessive pricing abuses are rarely challenged by European Union enforcers, largely as "the result of practical difficulties in assessment." ARIEL EZRACHI, EU COMPETITION LAW: AN ANALYTICAL GUIDE TO THE LEADING CASES 245 (4th ed. 2014).

80. Cf. Zephyr Teachout, Corporate Rules and Political Rules: Antitrust as Campaign Finance Reform (Fordham Law Legal Studies, Research Paper No. 2384182, 2014) (arguing for deconcentration as a remedy for the excessive political influence of large firms, on the view that economies in production are exhausted at substantially lower firm scale than are economies in rent-seeking).

81. See Donald F. Turner, The Scope of Antitrust and Other Economic Regulatory Policies, 82 HARV. L. REV. 1207, 1217 (1969) (recommending the restructuring of oligopolists into smaller units, either by charging them with joint monopolization under Section 2 of the Sherman Act or by adopting special legislation). See generally William E. Kovacic, Failed Expectations: The Troubled Past and Uncertain Future of the Sherman Act as a Tool for Deconcentration, 74 IOWA L. REV. 1105 (1989). 
policy that helped torpedo it a half century ago are no less powerful today, calling into question the viability of this no-fault approach.

\section{G. ADOPTING INEQUALITY AS AN EXPLICIT COMPETITION POLICY FOCUS OF THE ANTITRUST LAWS AND REGULATORY STATUTES}

Finally, antitrust law and regulatory agencies could address inequality more broadly by treating the reduction of inequality as an explicit antitrust goal. This policy would go beyond mere adoption of a consumer (rather than just an aggregate) welfare goal. Conduct might be considered anticompetitive if it harms middle- and lower-income consumers, even while benefiting wealthier consumers and shareholders. It also might be considered permissible if it benefits middle- and lower-income consumers at the expense of wealthier consumers and shareholders.

The Canadian Competition Tribunal adopted this type of distributional approach its 2002 Superior Propane merger decision, ${ }^{82}$ in response to an appellate decision holding that the governing statute required it to consider factors beyond economic efficiency, including distributional impacts. ${ }^{83}$ The Tribunal, working within a modified total welfare framework, concluded that it should give an elevated weight to the impact of the merger on the neediest consumers of the merging firms' products. Doing so did not make much difference in that case, however, because most purchasers were business customers and half of any profits from the exercise of market power would be shared with taxpayers. ${ }^{84}$

To implement this approach, the Supreme Court could recognize the economic and social concern with inequality as an antitrust goal, along with consumer welfare and efficiency. Alternatively (or in addition), Congress could add an explicit "public interest” goal to the Sherman and Clay-

82. Canada (Comm'r of Competition) v. Superior Propane Inc., [2002] 18 C.P.R. (4th) 417 (Comp. Trib.), aff'd, [2003] 3 F.C. 529 (Fed. Ct. App.). See generally Brian A. Facey, Canada's Propane Case Applies New Interpretation of Merger Efficiencies Defence: Balancing Weights Methodology Is King of the Hill, INT'L ANTITRUST BuLL., Fall 2002; Darwin V. Neher, David M. Russo \& J. Douglas Zona, Lessons from the SuperiorICG Merger, 12 GEO. MASON L. REV. 289 (2003).

83. Canada (Comm'r of Competition) v. Superior Propane Inc., [2001] 3 F.C. 185 (Fed. Ct. App.). See generally Brian A. Facey \& Dany H. Assaf, The Superior Propane Case: Canada's Efficiency Decision Overturned on Appeal, 15 ANTITRUST 90 (2001).

84. See generally Thomas W. Ross \& Ralph A. Winter, The Efficiency Defense in Merger Law: Economic Foundations and Recent Canadian Developments, 72 ANTITRUST L.J. 471, 489-93 (2005). 
ton Acts that would instruct the courts to interpret them as allowing the use of the antitrust laws to address distributional effects. ${ }^{85}$ Regulatory agencies that address competition issues under their existing "public interest” standards similarly could recognize distributional considerations as explicit and higher priority public interest goals. ${ }^{86}$

We recognize that implementing this approach in practice for mergers, which we will use as an example, would require undertaking a detailed distributional analysis. The difficulty of determining the downstream effects of price increases on intermediate inputs often would make this type of distributional analysis challenging. Thus, in application, the approach likely would focus primarily on mergers in markets for consumer products. Even in dealing with mergers in markets for final goods, moreover, it would be necessary to formulate rules for making tradeoffs among groups of buyers. ${ }^{87}$ Should harms to the poor count more than harms to the middle class? Can gains to the wealthy ever outweigh losses to those less wealthy - for example, if the gains are large and the losses small? If inequality is adopted as an antitrust goal, these will be important issues to debate.

Another issue raised by this approach is whether and how to deal with the wealth distribution of shareholders. In some cases, for example, some corporate equity might be owned by pension plans benefitting workers. The resulting distributional consequences might be ignored in most cases because stock ownership generally is highly skewed towards higherincome people, even when pension plans are taken into account. ${ }^{88}$ Taxes

85. The potential breadth of public interest standards in competition law, particularly with regard to mergers, is discussed in Harry First \& Eleanor M. Fox, Philadelphia National Bank, Globalization, and the Public Interest, 80 ANTITRUST L.J. (forthcoming 2015).

86. The FCC subsidizes communications services to low-income households pursuant to its statutory charge to assure universal service, and to assure that quality services are available at affordable rates nationwide. 47 U.S.C. §§151, 254(b)(1), 254(b)(3) (2012). The agency justified the Comcast-NBC Universal merger condition that the combined firm subsidize broadband for low-income consumers as promoting broadband deployment. Supra note 68. Reflecting the concerns of the country's high unemployment rate, South African merger law takes into account the impact of transactions on employment. See generally First \& Fox, supra note 85.

87. See Ross \& Winter, supra note 84, at 488-489 (Canada's Competition Tribunal looked to the progressivity of the Canadian tax code for guidance in determining the relative value of gains and losses to various wealth classes).

88. See the statistics cited at supra note 47. For this reason, we disagree with Professor Crane's view that the stockholdings of pension plans call into question whether owners of 
paid by corporations and their owners raise a related issue. If a substantial fraction of the increased income of the rich resulting from market power is taxed (taking into account differences between the rates applied to ordinary income and capital gains income), ${ }^{89}$ then the impact on inequality of those taxes will depend on how government revenues are distributed. ${ }^{90}$

There is also an issue of the extent to which this policy would be implemented in antitrust cases beyond mergers. Conduct might be considered permissible if it benefits lower-income consumers, even if the same conduct would be seen as anticompetitive if undertaken by higher-income consumers. For example, the law might permit this defense in a concerted monopsony price fixing case brought by payday lenders, but not in a concerted monpsony price fixing case brought against hospitals by nurses. Or, suppose that several auto manufacturers proposed to agree to charge lower prices for their entry-level models-or cars purchased by lowincome consumers - and offset these low prices with an agreement to jointly set the prices for certain of their luxury models. A focus on inequality might suggest permitting such this agreement. However, in both examples, the conduct could be seen an unacceptable "frontal attack" on the principles underlying the Sherman Act, ${ }^{91}$ and could be controversial for that reason.

\section{CONCLUSION}

A competition policy interest in inequality obviously would not arise in a political vacuum. ${ }^{92}$ It would more likely emerge as part of a broader concern with inequality, middle-class economic stagnation, and the political and economic power of large firms, ${ }^{93}$ tied to a successful political

capital are concentrated among those near the top of the wealth distribution. Crane, supra note 51 , at 9 .

89. On the progressivity of federal taxation, see CONGRESSIONAL BUDGET OfFICE, HistORICAL EFFECTIVE FEDERAL TAX RATES: 1975 TO 2005 (2007).

90. The impact on indirect purchasers raises another issue of how far to extend the analysis. Federal antitrust law (and the Merger Guidelines) typically do not trace through those effects today, and taking distribution into account would not necessarily raise an additional reason to do so.

91. See Nat'l Soc'y of Prof'l Eng'rs v. United States, 435 U.S. 679 (1978).

92. Cf. STIGLITZ, supra note 18, at 361 (when it comes to inequality, "politics and economics are inseparable”).

93. See Obama, supra note 27 (the problem of growing inequality and reduced upward economic mobility is the "defining challenge of our time"); see also Baker, supra note 46, at 2194-95; Peter Temin, Lessons from the Great Depression 136 (1989) 
movement. $^{94}$

In response, the antitrust and competition community would be expected to debate how best to account for distribution in implementing competition policy. While competition law is unlikely to take on the same importance as tax, labor, and trade policy for combating inequality, it might be called upon to complement and support those policies. The range of competition policy options set out here can be a useful starting point for a policy debate. Further analysis can identify the advantages and disadvantages of each. In that way, better competition policies can be adopted, if and when the inequality issue reaches the front burner of politics and policy. We are looking forward to participating in this important discus-

("Capitalism thrives during economic stability" and "wilts in depression," while "[s]ocialism appears to be the reverse," so "a renewed depression" would be expected to lead eventually to "a swing of the policy pendulum back toward socialism.”); $c f$. Acemoglu, supra note 31 (noting that the adverse consequences of the continuing close connections between the financial industry and politicians "may lead to a strong backlash, taking aim not only at the super-rich in the financial sector but also at those in other sectors”).

94. See Baker, supra note 46, at 2195 (“[A] successful center/left coalition may be predicated on an electoral shift . . . .”); cf. JAMES CHACE, 1912: WiLSON, ROOSEVELT, TAFT AND DeBs - The Election That ChANGED THE Country 100 (2004) (“The Progressive movement at first was made up of consumers and taxpayers who were challenging the accumulated wealth and power of such men as John D. Rockefeller, Andrew Carnegie, Henry C. Frick, and J. P. Morgan. By 1912, however, progressivism was becoming more of a movement of farmers and industrial workers seeking relief from the onerous power of the great monopolies.”). Such a movement today might involve the political mobilization of the less affluent. The bottom $60 \%$ of the population is substantially less likely to vote than the top $40 \%$, and substantially more likely to favor more government help for the needy, even if it means more debt. PEW RESEARCH CENTER, THE Politics of FiNANCIAL INSECURITY (2015), available at http://www.people-press.org/2015/01/08/thepolitics-of-financial-insecurity-a-democratic-tilt-undercut-by-low-participation. Even if those left behind as the rich grow richer organize politically to challenge big business and the wealthy, however, they may not succeed. The anti-government Tea Party, not the interventionist Occupy movement, was the more successful political movement arising in the immediate wake of the financial crisis. Inequality may even be self-reinforcing: an oligarchy may exploit its power to change the rules of the political game, allowing it to entrench its economic position. See BARTELS, supra note 29 (the political preferences of political elites have led to policies that enhance economic inequality); STIGLITZ, supra note 18, at 131 (not only do "the rules of the economic game, set by the political process, stack the cards in favor of the 1 percent," so too do "the rules of the political game"); WINTERS, supra note 29, at 220-54 (discussing ways the U.S. economic elite have defended their position politically); $c f$. LAWRENCE LESSIG, REPUBLIC, LOST: HOW MONEY CORRUPTS CONGRESS - AND A PLAN TO STOP IT (2011); ZINGALES, supra note 51 (calling for greater competition to protect the U.S. economy from the dangers of crony capitalism). 
sion with our antitrust colleagues. 